\title{
Exopolysaccharide and Siderophore Production Ability of Zn Solubilizing Bacterial Strains Improve Growth, Physiology and Antioxidant Status of Maize and Wheat
}

\author{
Saher Naseem ${ }^{1}$, Azhar Hussain ${ }^{1 *}$, Xuikang Wang ${ }^{2 * *}$, Zafar Iqbal ${ }^{1}$, Adnan Mustafa ${ }^{3}$, \\ Muhammad Zahid Mumtaz ${ }^{4}$, Amir Manzoor ${ }^{5}$, Moazzam Jamil ${ }^{1}$, Maqshoof Ahmad ${ }^{1}$ \\ ${ }^{1}$ Department of Soil Science, The Islamia University of Bahawalpur, 63100, Pakistan \\ ${ }^{2}$ College of Life Sciences, Yan'an University, Yan'an 716000, China \\ ${ }^{3}$ Biology Centre CAS, SoWa RI, Na Sadkach 7, 37005, Ceske Budejovice, Czech Republic \\ ${ }^{4}$ Institute of Molecular Biology and Biotechnology, The University of Lahore, Defence Road Campus, \\ Lahore, 54590, Pakistan \\ ${ }^{5}$ Farm Management, Faculty of Agriculture \& Environment, The Islamia University of Bahawalpur, 63100, Pakistan
}

Received: 22 May 2021

Accepted: 27 July 2021

\begin{abstract}
Zinc solubilizing bacteria can solubilize zinc oxide and make them available for plant uptake. Rhizobacteria were isolated and screened for exopolysaccharide (EPS) and siderophore production and plant growth promotion. The strains IUB2, IUB3, IUB6, IUB10 and IUB11 showed potential zinc solubilization and plant growth promotion. The maximum increase of $31 \%$ and $40 \%$ in shoot length was recorded by the strain IUB3 in maize and wheat, respectively. The strain IUB11 showed the maximum increase of wheat vs. maize; 29 vs. $32 \%$ and 40 vs. $39 \%$ in dry biomass and root length. Furthermore, maximum bacterial colonization of $53 \times 10^{5} \mathrm{CFU} \mathrm{g}^{-1}$ root in wheat found by IUB2. While in maize $\left(81 \times 10^{5} \mathrm{CFU} \mathrm{g}^{-1}\right.$ root $)$ found in maize by IUB3. All the tested isolates showed positive results for the exopolysaccharides, siderophore, $\mathrm{HCN}$, catalase, protease and cellulose-degrading activities. Only strains IUB2 and IUB10 showed positive results for phosphate solubilization. Moreover, these strains were identified as Bacillus subtilis-IUB2, Bacillus velezensis-IUB3, Bacillus subtilis-IUB6, Bacillus vallismortis-IUB10 and Bacillus megaterium-IUB1. Our study found that inoculation of the selected zinc solubilizing bacterial strains enhanced the growth of both maize and wheat crops. Hence these strains can be utilized as biofertilizers in future.
\end{abstract}

Keywords: Zinc solublization, Exopolysaccharide, Siderophore, Bacillus sp.

e-mail: azharhaseen@gmail.com

**e-mail: wangxiukang@yau.edu.cn 


\section{Introduction}

Zinc is an essential micronutrient. Being a part of various metabolic activities, it plays a role in photosynthesis and respiration. Zinc is also responsible for the stimulation of many enzymes [1]. It is essential for the development of plant, humans as well as animals. Zinc is compulsory for obtaining maximum fruit size, yield and production of crop plants. It is involved in the functioning of carbonic anhydrase enzyme that is component of most of the photosynthetic materials and essential for chlorophyll formation [2]. Zinc is involved in the proteins formation, enzymes stimulation, metabolism and oxidation of biological compounds. It has been found that zinc and inorganic fertilizers enhance the crop value; however, the shortage of these components is the base for decreasing the protein, carbohydrates and ribonucleic acid formation which results in the reduction of crop growth and yield [3].

Zinc deficiency occurs mainly in females and children of 3-5 years old, leading to hidden hunger. It was found that over 2 billion people globally are suffering from hidden hunger of micronutrients, mainly $\mathrm{Zn}, \mathrm{Se}, \mathrm{I}$, and $\mathrm{Fe}[4,5]$. The problem of micronutrient deficiency is also spreading in Pakistan due to arid to semi-arid climate, alkaline soils with low organic matter and high temperature [6]. The environmental conditions lead to a high evaporation rate from the surface, leaving salts behind, resulting in deficiency of micronutrients and high soil $\mathrm{pH}$ [7]. Other reasons for the deficiency of micronutrients are the cultivation of high yielding crops, intensive cropping system, poor recycling of crop residues, and excessive fertilization [8].

For proper growth and development, plants require $0.05 \mathrm{~kg} \mathrm{ha}^{-1}$ of zinc. Among applied zinc fertilizers, a large amount of $\mathrm{Zn}$ is not available to the crop plants [9]. Farmers usually spread high concentration of inorganic fertilizers, which becomes a great risk for human health and causes atmospheric pollution [10]. Inorganic fertilizers dissolve gradually in the soil solution at a level that is not enough to meet the adequate $\mathrm{Zn}$ concentration for the proper growth and development of crop plants [11]. Therefore, PGPR is considering best in the sustainable and biological farming system for effective utilization of natural resources of $\mathrm{Zn}$ present in the soil and to minimize the harmful participation of inorganic fertilizers in the atmosphere [12], to increase the growth and yield of crops [13]. So, PGPR are consider best in the sustainable and biological farming system for effective utilization of natural resources of $\mathrm{Zn}$ present in the soil and to minimize the harmful participation of inorganic fertilizers in the atmosphere [14] with the objective of increasing the growth and yield of crops [15]. Soil organic matter stabilize nutrients availability for plant uptake that resulted in enhanced nutrient use efficiency and high yield [16].

Plant growth-promoting rhizobacteria (PGPR) are the bacteria that can solubilize unavailable zinc present in soil which results ultimately in increased plant growth [17]. PGPR converts the various inaccessible forms of zinc like zinc phosphate, zinc carbonate and zinc oxide that are extensively found in the soil to the accessible form for plant uptake [18]. Bacteria release various chelating metabolites in the rhizosphere of plants, including siderophore, which are considered an essential source of micronutrients readily available to plants like $\mathrm{Zn}$ and Fe [19]. By making complexes with $\mathrm{Zn}$, microbial siderophore increases the available plant fraction of it [6].

Zinc solubilizing bacteria make the $\mathrm{Zn}$ available by different processes like organic acid production, the release of siderophore and protons [20]. These bacteria also release gluconic acid, which converts the insoluble $\mathrm{Zn}$ to a soluble form and enhances the growth and development of cereals [21]. The availability of micronutrients in the soil is highly dependent on soil $\mathrm{pH}$ [22]. Zinc availability can be increased by lowering the $\mathrm{pH}$ of soil. Zinc solubilizing bacteria (ZSB) produces organic acids that decrease soil $\mathrm{pH}$ and enhance the bioavailable zinc contents in the soil [17].

Application of $\mathrm{Zn}$ solubilizing bacteria with inorganic fertilizer is likely considered the best soil fertility management strategy that can improve agricultural output. Such benefits may not be achieved if we use organic or inorganic fertilizer alone. Hence, the present study hypothesized as the application of zinc solubilizing bacteria and enriched compost may enhance uptake of zinc and promote plant growth. Therefore, the present experiment has been planned with the objectives of isolation, characterization, identification and evaluation of the potential zinc solubilizing bacteria to promote seedling growth of maize and wheat. The crops maize and wheat have been selected to evaluate zinc solubilizing bacteria because these are important staple foods globally.

\section{Experimental Procedures}

Twenty-five zinc solubilizing bacterial isolates were isolated from wheat and maize rhizosphere in Bahawalpur region. Bahawalpur is main district of Cholistan desert lies $117 \mathrm{~m}$ above sea level. It is located on $29.41^{\circ}$ latitude and $71.67^{\circ}$ longitude. The mean annual temperature in Bahawalpur is $25.6^{\circ} \mathrm{C}$ with annual rainfall of $143 \mathrm{~mm}$.

\section{Zn Solubilization Assay}

$\mathrm{Zn}$ solubilizing ability of bacterial strains was determined as defined by Fasim et al., [23]. The formation of a halo zone around the colony was an indication of a positive result. The halo zone diameter, as well as colony diameter, was measured. Solubilization efficiency and solubilization index was calculated. For the quantitative zinc solubilization test, tris minimal broth media amended with $0.1 \% \mathrm{ZnO}$ was inoculated with respective strains in $100 \mathrm{~mL}$ conical 
flask and incubate at $30 \pm 2^{\circ} \mathrm{C}$ in a shaking incubator at $100 \mathrm{rpm}$. After 15 days of incubation, solubilized zinc content was measured through the atomic absorption spectrophotometer using standard protocol [24].

\section{Screening of Zn Solubilizing Bacteria Based on Growth Promotion under Axenic Conditions}

Twelve bacterial isolates having high zinc solubilizing potential were selected for further evaluation in jar trials. The isolates were screened for plant growth promoting ability in growth room. The conditions were adjusted as $12 \mathrm{hrs}$ light (1000 flux) and $12 \mathrm{hrs}$ dark. Maize crop was grown in the growth room at $14-28^{\circ} \mathrm{C}$ temperature with $60-75 \%$ humidity. Wheat crop was sowed in the growth room at $15-20^{\circ} \mathrm{C}$ temperature and $70-90 \%$ humidity. Jars were filled with sterilized sand. Irrigation was done with half strength Hoagland solution [25]. The experiment was carried out in a completely randomized design with 13 treatments (control, IUB2, IUB3, IUB4, IUB5, IUB6, IUB9, IUB10, IUB11, IUB12, IUB14, IUB17 and IUB23) and 6 replications. Seeds of wheat variety Johar 2016 and maize variety DK-9108 were inoculated with zinc solubilizing bacteria by dipping of seed for half hour in broth culture of respective strains. While in the case of control, uninoculated seeds were sown. After 35 days of sowing, seedlings were harvested. Root development, growth, physiological and biochemical parameters were recorded.

\section{Root Colonization Assay}

Seven days after sowing, seedlings were gently uprooted from three replication and washed with tap water. Surface sterilization of roots was done by dipping them in $2 \%$ mercuric chloride solution for the $30 \mathrm{~S}$ followed by dipping in $95 \%$ ethanol for 1 minute and 6 time washing with sterilized distilled water. Two hundred mili gram (200 mg) of surface-sterilized roots macerated and ground in $5 \mathrm{~mL}$ sterilized distilled water with sanitized mortar and pestle. After shaking, the bacterial suspension was diluted from $10^{-1}$ to $10^{-6}$. Add $1 \mathrm{ml}$ of each dilution into petri dishes containing sterilized general purpose media and incubated at 30 ${ }^{\circ} \mathrm{C}$ for 48 hours. Then, the bacterial population was counted in terms of colony forming units (CFU) using digital colony counter (Digital S model, Selecta P) described by Iqbal et al. [26].

\section{Characterization of Selected Isolates}

The selected strains were characterized for growthpromoting and biochemical attributes. Phosphate solubilizing potential of the isolates was evaluated by forming halo zone in Pikovskya's agar medium after 3-5 days of incubation at $28^{\circ} \mathrm{C}$ which was considered positive [27]. Siderophore production potential of the isolated strains was examined as defined by Schwyn and Neilands [28]. For this purpose, Chrome azurol S (CAS) blue agar plate was spot inoculated with actively growing strains and incubated for 3 days at $37^{\circ} \mathrm{C}$. The appearance of the yellow-orange halo zone around the colony showed the formation of siderophore on the agar plate. Exopolysaccharide production (EPS) was determined by inoculating the strains on De Man Ragosa and Sharp (MRS) agar media and incubated at $30^{\circ} \mathrm{C}$ for 3 days. The mucoid growth of colonies considered as EPS positive. Following Patten and Glick [29], the production of indole-3-acetic acid (IAA) was in the presence and absence of $\mathrm{L}$ tryptophan. The biochemical activities such as cellulose degradation, oxidase, protease, catalase and urease activity $\mathrm{HCN}$ production was determined [26].

\section{Identification of Selected Zinc Solubilizing Bacterial Isolates}

The selected isolates were identified through $16 \mathrm{~S}$ rRNA gene sequencing technique by the amplification sequencing and bioinformatics procedure. Adopting proteinase $\mathrm{K}$ treatment rough genetic material of selected bacterial isolates IUB2, IUB3, IUB6, IUB10 and IUB11 was isolated from the bacterial cells [30]. Then Identification of selected zinc solubilizing bacterial isolates was done by using the rough genetic material according to the method defined by Hussain et al. [17].

\section{Statistical Analysis}

The data obtained from the above tests was subjected to statistical model 8.1 and means were compared by least significant difference to see the significance of results [31].

\section{Results and Discussion}

\section{Isolation of Zinc Solubilizing Rhizobacterial Strains}

Twenty-five zinc solubilizing bacterial colonies were isolated from maize and wheat rhizosphere and coded as IUB1, IUB2, IUB3, ........, IUB25. The ability of zinc solubilizing bacteria to solubilize the insoluble source of zinc is presented in Table 1 . Data depicted that all the zinc solubilizing bacterial isolates solubilized the insoluble zinc compound $(\mathrm{ZnO})$. The formation of a clear halo zone indicates the solubilization of $\mathrm{ZnO}$ by ZSB. The strain IUB11 showed maximum halo zone diameter $(2.5 \mathrm{~cm})$ and halo zone area $\left(12.6 \mathrm{~cm}^{2}\right)$. It was found that strain IUB10 gave maximum colony diameter $(1.6 \mathrm{~cm})$. The strains IUB9 and IUB11 were the following strains that showed better results for colony diameter. Both these strains showed $1.5 \mathrm{~cm}$ colony diameter. Data regarding zinc solubilization efficiency showed 
Table 1. Zn solubilizing potential of rhizobacterial isolates.

\begin{tabular}{|c|c|c|c|c|c|c|}
\hline Bacterial isolate & $\begin{array}{c}\text { Halozone } \\
\text { diameter }(\mathrm{cm})\end{array}$ & $\begin{array}{l}\text { Colony diameter } \\
(\mathrm{cm})\end{array}$ & $\begin{array}{l}\text { Halozone area } \\
\qquad\left(\mathrm{cm}^{2}\right)\end{array}$ & ZSE & ZSI & $\begin{array}{l}\text { Zn concentration } \\
\qquad\left(\mathrm{mg} \mathrm{L}^{-1}\right)\end{array}$ \\
\hline Control & - & - & - & - & - & $8.0 \mathrm{~g}$ \\
\hline IUB1 & $0.6 \mathrm{~m}$ & $0.3 \mathrm{ij}$ & $0.6 \mathrm{~lm}$ & $217 \mathrm{de}$ & $2.70 \mathrm{a}-\mathrm{c}$ & $8.9 \mathrm{a}$ \\
\hline IUB2* & $1.6 \mathrm{~d}$ & $1.0 \mathrm{de}$ & $5.2 \mathrm{f}$ & $157 \mathrm{f}-\mathrm{i}$ & $2.57 \mathrm{a}-\mathrm{c}$ & $8.6 \mathrm{~b}$ \\
\hline IUB3* & $1.9 \mathrm{c}$ & $0.9 \mathrm{~g}$ & $5.9 \mathrm{e}$ & $216 \mathrm{de}$ & $3.10 \mathrm{a}-\mathrm{c}$ & $8.4 \mathrm{de}$ \\
\hline IUB4* & $1.8 \mathrm{c}$ & $1.2 \mathrm{c}$ & $7.4 \mathrm{~d}$ & $149 \mathrm{~g}-\mathrm{i}$ & $2.59 \mathrm{a}-\mathrm{c}$ & $8.3 \mathrm{e}$ \\
\hline IUB5* & $1.3 \mathrm{f}$ & $1.0 \mathrm{~d}$ & $4.4 \mathrm{~g}$ & $129 \mathrm{hi}$ & $2.33 \mathrm{bc}$ & $8.5 \mathrm{~cd}$ \\
\hline IUB6* & $2.1 \mathrm{~b}$ & $1.2 \mathrm{c}$ & $8.4 \mathrm{c}$ & $172 \mathrm{e}-\mathrm{i}$ & $2.84 \mathrm{a}-\mathrm{c}$ & $9.0 \mathrm{a}$ \\
\hline IUB7 & $0.8 \mathrm{ij}$ & $0.3 \mathrm{ij}$ & 1.01 & $328 \mathrm{ab}$ & $3.58 \mathrm{ab}$ & $9.0 \mathrm{a}$ \\
\hline IUB8 & $0.7 \mathrm{kl}$ & $0.2 \mathrm{j}$ & $0.6 \mathrm{~lm}$ & $350 \mathrm{a}$ & $3.57 \mathrm{ab}$ & $8.7 \mathrm{~b}$ \\
\hline IUB9* & $1.9 \mathrm{c}$ & $1.5 \mathrm{~b}$ & $8.7 \mathrm{c}$ & $127 \mathrm{hi}$ & $2.49 \mathrm{bc}$ & $8.1 \mathrm{f}$ \\
\hline IUB10* & $2.0 \mathrm{~b}$ & $1.6 \mathrm{a}$ & $10.4 \mathrm{~b}$ & $127 \mathrm{hi}$ & $2.52 \mathrm{bc}$ & $8.9 \mathrm{a}$ \\
\hline IUB11* & $2.5 \mathrm{a}$ & $1.5 \mathrm{ab}$ & $12.6 \mathrm{a}$ & $161 \mathrm{e}-\mathrm{i}$ & $2.89 \mathrm{a}-\mathrm{c}$ & $9.0 \mathrm{a}$ \\
\hline IUB12* & $1.3 \mathrm{f}$ & $0.9 \mathrm{fg}$ & $3.9 \mathrm{~h}$ & 148 g-i & $2.43 \mathrm{bc}$ & $8.4 \mathrm{de}$ \\
\hline IUB13 & $0.6 \mathrm{~lm}$ & $0.3 \mathrm{i}$ & $0.7 \mathrm{~lm}$ & $192 \mathrm{e}-\mathrm{g}$ & $2.57 \mathrm{a}-\mathrm{c}$ & $8.3 \mathrm{e}$ \\
\hline IUB14* & $1.5 \mathrm{de}$ & $0.9 \mathrm{e}-\mathrm{g}$ & $4.6 \mathrm{~g}$ & $161 \mathrm{e}-\mathrm{i}$ & $2.56 \mathrm{a}-\mathrm{c}$ & $8.5 \mathrm{c}$ \\
\hline IUB15 & $1.0 \mathrm{gh}$ & $0.6 \mathrm{~h}$ & $1.9 \mathrm{jk}$ & 178 e-h & $2.56 \mathrm{a}-\mathrm{c}$ & $8.1 \mathrm{f}$ \\
\hline IUB16 & $1.1 \mathrm{~g}$ & $0.6 \mathrm{~h}$ & $2.4 \mathrm{j}$ & 174 e-h & $2.49 \mathrm{bc}$ & $8.1 \mathrm{f}$ \\
\hline IUB17* & $1.5 \mathrm{de}$ & $1.0 \mathrm{de}$ & $4.8 \mathrm{fg}$ & $147 \mathrm{~g}-\mathrm{i}$ & $2.47 \mathrm{bc}$ & $8.2 \mathrm{f}$ \\
\hline IUB18 & 0.9 hi & $0.6 \mathrm{~h}$ & $1.8 \mathrm{k}$ & 164 e-i & $2.42 \mathrm{bc}$ & $8.1 \mathrm{f}$ \\
\hline IUB19 & $0.8 \mathrm{jk}$ & $0.2 \mathrm{j}$ & $0.8 \mathrm{~lm}$ & $356 \mathrm{a}$ & $3.93 \mathrm{a}$ & $8.1 \mathrm{f}$ \\
\hline IUB20 & $0.6 \mathrm{~lm}$ & $0.3 \mathrm{i}$ & $0.7 \mathrm{~lm}$ & 194 e-g & $2.64 \mathrm{a}-\mathrm{c}$ & $8.1 \mathrm{f}$ \\
\hline IUB21 & $0.6 \mathrm{~m}$ & $0.2 \mathrm{j}$ & $0.5 \mathrm{~m}$ & $283 \mathrm{bc}$ & $3.03 \mathrm{a}-\mathrm{c}$ & $8.1 \mathrm{f}$ \\
\hline IUB22 & $0.6 \mathrm{~lm}$ & $0.2 \mathrm{j}$ & $0.5 \mathrm{~lm}$ & $267 \mathrm{~cd}$ & $2.87 \mathrm{a}-\mathrm{c}$ & $8.1 \mathrm{f}$ \\
\hline IUB23* & $1.4 \mathrm{ef}$ & $1.0 \mathrm{~d}-\mathrm{f}$ & $4.5 \mathrm{~g}$ & 149 g-i & $2.49 \mathrm{bc}$ & $8.1 \mathrm{fg}$ \\
\hline IUB24 & $0.5 \mathrm{~m}$ & $0.3 \mathrm{ij}$ & $0.5 \mathrm{~m}$ & $211 \mathrm{~d}-\mathrm{f}$ & $2.72 \mathrm{a}-\mathrm{c}$ & $8.1 \mathrm{fg}$ \\
\hline IUB25 & $1.1 \mathrm{~g}$ & $0.9 \mathrm{e}-\mathrm{g}$ & $3.1 \mathrm{i}$ & $114 \mathrm{i}$ & $2.11 \mathrm{c}$ & $8.1 \mathrm{fg}$ \\
\hline$L S D(p \leq 0.05)$ & 0.1002 & 0.0803 & 0.4342 & 59.237 & 1.3770 & 0.1056 \\
\hline $\mathrm{CV}$ & 4.97 & 6.53 & 6.91 & 18.54 & 30.62 & 0.77 \\
\hline
\end{tabular}

Data are shown as mean of five replicates. * strains showed better results and were selected for further evaluation. Means followed by same letter(s) within the column are not significantly different according to least significance difference (LSD) test at $\mathrm{p} \leq 0.05$. ZSE; Zinc solubilizing efficiency, ZSI; Zinc solubilizing index

that minimum zinc solubilization efficiency was given by the strain IUB25, which showed $114 \%$ zinc solubilization efficiency. Maximum zinc solubilization efficiency and $\mathrm{Zn}$ solubilization index was given by the strain IUB19 with $356 \%$ zinc solubilization efficiency and $3.93 \mathrm{Zn}$ solubilization index. Other strains that gave better results for zinc solubilization index were IUB7, IUB8 and IUB3. All these strains expressed 3.58, 3.57 and 3.1 zinc solubilization index, respectively. These bacterial isolates were further tested for quantitative zinc solubilization assay to calculate the quantity of solubilized zinc in the Tris minimal liquid broth culture amended with $0.1 \% \mathrm{ZnO}$. Maximum solubilized zinc concentration (9.0 $\left.\mathrm{mg} \mathrm{L}^{-1}\right)$ was observed by strain IUBB11. While the strains IUB1 and IUB2 was next after IUB11 that showed $8.9 \mathrm{mg} \mathrm{L}^{-1}$ solubilized zinc content. Based on zinc solubilization, twelve bacterial isolates were selected for further evaluation in jar trial for plant growth promotion attributes. 
Table 2. Potential of zinc solubilizing rhizobacteria to improve growth parameters of maize in jar trial.

\begin{tabular}{|c|c|c|c|c|c|}
\hline \multirow{2}{*}{ Treatments } & Shoot length & Root length & \multirow{2}{*}{$\frac{\text { Dry biomass }}{\left(\mathrm{g} \mathrm{jar}^{-1}\right)}$} & \multirow{2}{*}{$\frac{\text { R/S Ratio }}{-}$} & \multirow{2}{*}{$\frac{\text { Root colonization }}{\mathrm{CFU} \times 10^{5} \mathrm{~mL}^{1}}$} \\
\hline & \multicolumn{2}{|c|}{$(\mathrm{cm})$} & & & \\
\hline Control & $29 \mathrm{~g}$ & $8.6 \mathrm{~h}$ & $1.46 \mathrm{j}$ & $0.33 \mathrm{~g}$ & $18 \mathrm{j}$ \\
\hline IUB2 & $37 \mathrm{a}$ & $10.8 \mathrm{~d}$ & $1.87 \mathrm{~b}$ & $0.37 \mathrm{a}$ & $53 \mathrm{a}$ \\
\hline IUB3 & $38 \mathrm{a}$ & $11.3 \mathrm{c}$ & $1.82 \mathrm{c}$ & $0.36 \mathrm{~b}$ & $27 \mathrm{e}$ \\
\hline IUB4 & $33 \mathrm{~d}-\mathrm{f}$ & $10.6 \mathrm{de}$ & $1.71 \mathrm{ef}$ & 0.34 ef & $32 \mathrm{~d}$ \\
\hline IUB5 & $32 \mathrm{f}$ & $8.8 \mathrm{~h}$ & $1.72 \mathrm{e}$ & 0.34 ef & $35 \mathrm{c}$ \\
\hline IUB6 & $35 \mathrm{bc}$ & $11.4 \mathrm{c}$ & $1.77 \mathrm{~d}$ & $0.35 \mathrm{~b}$ & $37 \mathrm{c}$ \\
\hline IUB9 & $34 \mathrm{c}-\mathrm{e}$ & $10.4 \mathrm{e}$ & $1.69 \mathrm{f}-\mathrm{h}$ & $0.34 \mathrm{~d}-\mathrm{f}$ & $22 \mathrm{gh}$ \\
\hline IUB10 & $35 \mathrm{~b}-\mathrm{d}$ & $11.6 \mathrm{~b}$ & $1.94 \mathrm{a}$ & $0.37 \mathrm{a}$ & $20 \mathrm{hi}$ \\
\hline IUB11 & $36 \mathrm{ab}$ & $12.1 \mathrm{a}$ & $1.93 \mathrm{a}$ & $0.37 \mathrm{a}$ & $24 \mathrm{fg}$ \\
\hline IUB12 & $32 \mathrm{ef}$ & $9.9 \mathrm{f}$ & $1.70 \mathrm{e}-\mathrm{g}$ & $0.34 \mathrm{de}$ & $45 \mathrm{~b}$ \\
\hline IUB14 & $33 \mathrm{~d}-\mathrm{f}$ & $10.6 \mathrm{de}$ & $1.66 \mathrm{hi}$ & $0.33 \mathrm{fg}$ & $25 \mathrm{f}$ \\
\hline IUB17 & $29 \mathrm{~g}$ & $9.8 \mathrm{f}$ & $1.67 \mathrm{~g}-\mathrm{I}$ & $0.35 \mathrm{bc}$ & $19 \mathrm{ij}$ \\
\hline IUB23 & $33 \mathrm{ef}$ & $9.4 \mathrm{~g}$ & $1.66 \mathrm{I}$ & 0.35 & $52 \mathrm{a}$ \\
\hline $\operatorname{LSD}(p \leq 0.05)$ & 1.683 & 0.231 & 0.027 & 0.008 & 2.029 \\
\hline $\mathrm{CV}$ & 2.99 & 1.32 & 0.92 & 1.37 & 3.86 \\
\hline
\end{tabular}

Data are shown as mean of five replicates. Means followed by same letter(s) within the column are not significantly different according to least significance difference (LSD) test at $\mathrm{p} \leq 0.05$. R/S ratio; root to shoot ratio

\section{Maize Trial}

\section{Growth Promoting Activity of Rhizobacterial Isolates in Maize Seedling}

Healthy seeds of maize were procured from the local market. Seeds were surface sterilized and based on $\mathrm{Zn}$ solubilization efficiency; selected bacterial isolates were used for plant inoculation experiment. The selected bacterial isolates were used to study their influence on plant growth promotion of maize seedlings in terms of increase in shoot length, root length and dry biomass. The inoculated seedlings showed a tremendous increase in dry weight $(33 \%)$ by strain IUB11 while the highest root/shoot ratio was given by the strain IUB2 $(15 \%)$ in comparison to the uninoculated control (Table 2). The isolates IUB3, IUB6, IUB10 and IUB11 also showed significant increased upto 11, 9, 13 and $14 \%$ in root/shoot ratio, respectively.

The seed inoculation with zinc solubilizing rhizobacteria significantly enhanced root colonization under axenic conditions (Table 2). The maximum root colonization $\left(53 \times 10^{4} \mathrm{cfu} \mathrm{g}^{-1}\right.$ root $)$ was recorded by strain IUB2 followed by strains IUB23, IUB12 and IUB 6 that showed root colonization up to $52 \times 10^{4} \mathrm{cfu} \mathrm{g}^{-1}$ root, $45 \times 10^{4} \mathrm{cfu} \mathrm{g}^{-1}$ root and $37 \times 10^{4} \mathrm{cfu} \mathrm{g}^{-1}$ root, respectively. Minimum root colonization was observed by strain IUB17 that showed $19 \times 104 \mathrm{cfu}$ g- 1 root among applied treatments.
Furthermore, selected strains improved leaf surface area and root growth such as average root diameter, root surface area and root volume. Data represented that inoculated seedlings with zinc solubilizing isolates significantly influenced the leaf and root growth (Fig. 1), which showed a tremendous increase in the leaf area (35\%), root surface area $(30 \%)$ and root volume $(32 \%)$ by the strain IUB2 as compared to uninoculated control. The result depicted that all these strains showed significant results over uninoculated control and all the zinc solubilizing bacterial strains improved the growth of maize crop.

\section{Effect of Zinc Solubilizing Bacterial Isolates on Physiology and Antioxidant Enzyme System of Maize Seedlings}

Data in Table 3, demonstrated the effect of zinc solubilizing bacteria on physiological attributes and antioxidant enzyme system of maize. The results revealed that applying zinc solubilizing bacteria showed a greater impact on chlorophyll a, chlorophyll $\mathrm{b}$, and carotenoids. The strain IUB2 showed the maximum increase in chlorophyll a (14\%), chlorophyll b (13\%), and carotenoids (12\%) as compared to control. The strain IUB4 and IUB9 showed similar effect on chlorophyll a, where $6 \%$ increase was recorded. The chlorophyll b content of the strains IUB4, IUB5, 

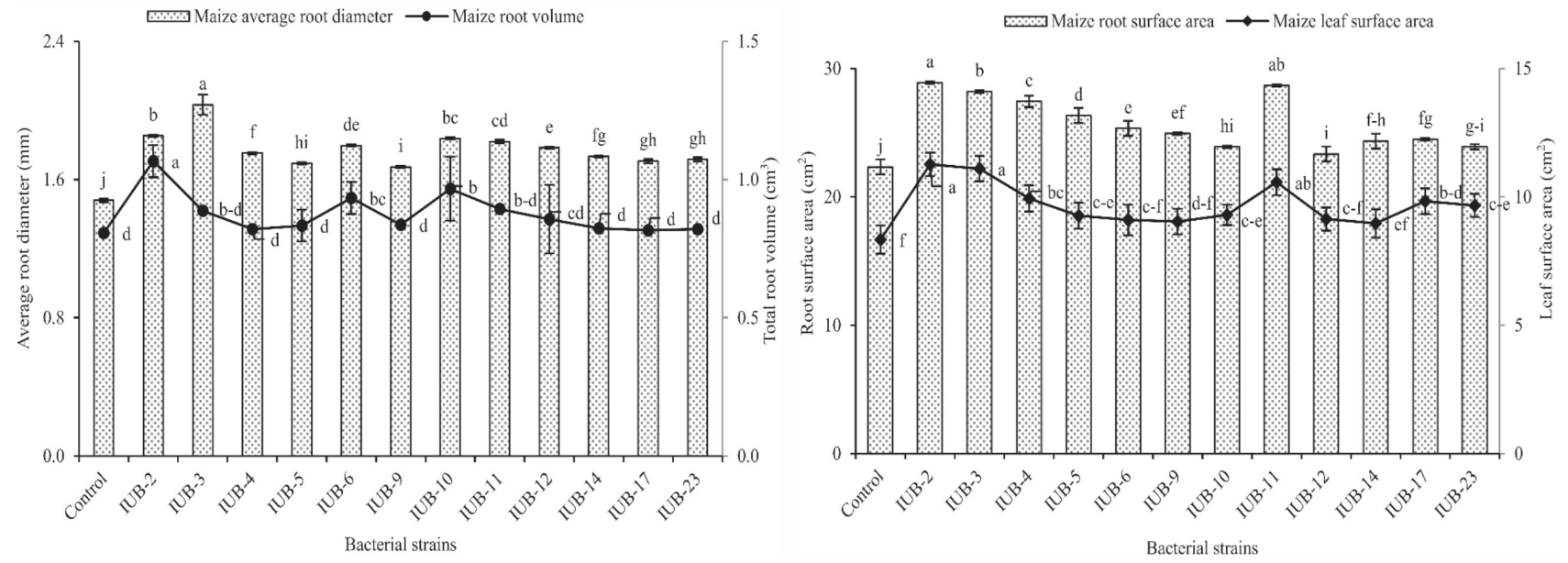

Fig. 1. Potential of zinc solubilizing rhizobacteria to improve root growth and shoot surface area in maize seedlings. Bars sharing same letter(s) does not differ significantly as par 5\% level of probability. Bars represent average root diameter a) and root surface area b) while Line represent total root volume a) and leaf surface area b).

IUB9, and IUB17 was found to have increased by $1 \%$, which was non-significant compared to the control. However, when compared to control, the strains IUB2 and IUB3 provided substantial results, with chlorophyll b contents increasing by $14 \%$ and $12 \%$, respectively. The strains IUB5, IUB9, IUB12, and IUB23 provided similar results, with a $5 \%$ increase in carotenoid content when compared to the control. However, strain IUB2 showed the maximum increase of $12 \%$ in carotenoid contents.

The production of antioxidant enzymes in the maize crop was also improved by zinc solubilizing bacteria (Table 3). The strain IUB2 performed best when compared with the uninoculated control in terms

Table 3. Potential of zinc solubilizing rhizobacteria to improve physiological parameters of maize in jar trial.

\begin{tabular}{|c|c|c|c|c|c|c|c|c|}
\hline \multirow{2}{*}{ Isolates } & Chlorophyll a & Chlorophyll b & Carotenoid & SOD & POD & CAT & APX & POX \\
\hline & \multicolumn{3}{|c|}{$\left(\mu \mathrm{g} \mathrm{g}^{-1}\right)$} & \multicolumn{5}{|c|}{ (Units $\mathrm{g}^{-1} \mathrm{FW}$ ) } \\
\hline Control & $0.62 \mathrm{i}$ & $0.62 \mathrm{c}$ & $0.98 \mathrm{~d}$ & $124 \mathrm{j}$ & $0.91 \mathrm{e}$ & $7.4 \mathrm{~h}$ & $117 \mathrm{~m}$ & $0.25 \mathrm{e}$ \\
\hline IUB2 & $0.71 \mathrm{a}$ & $0.70 \mathrm{a}$ & $1.10 \mathrm{a}$ & $141 \mathrm{a}$ & $1.04 \mathrm{a}$ & $8.5 \mathrm{a}$ & $130 \mathrm{c}$ & $0.28 \mathrm{ab}$ \\
\hline IUB3 & $0.70 \mathrm{ab}$ & $0.67 \mathrm{ab}$ & $1.09 \mathrm{a}$ & $133 \mathrm{~cd}$ & $1.00 \mathrm{a}-\mathrm{c}$ & $8.5 \mathrm{a}$ & $129 \mathrm{~d}$ & $0.27 \mathrm{a}-\mathrm{c}$ \\
\hline IUB4 & $0.66 \mathrm{ef}$ & $0.62 \mathrm{c}$ & $1.00 \mathrm{~cd}$ & $130 \mathrm{fg}$ & $0.97 \mathrm{~b}-\mathrm{e}$ & $7.6 \mathrm{fg}$ & 1201 & $0.27 \mathrm{~b}-\mathrm{d}$ \\
\hline IUB5 & $0.63 \mathrm{hi}$ & $0.62 \mathrm{c}$ & $1.03 \mathrm{a}-\mathrm{d}$ & $132 \mathrm{de}$ & $0.96 \mathrm{~b}-\mathrm{e}$ & $7.8 \mathrm{de}$ & $122 \mathrm{k}$ & $0.26 \mathrm{de}$ \\
\hline IUB6 & $0.69 \mathrm{bc}$ & $0.67 \mathrm{ab}$ & $1.07 \mathrm{ab}$ & $138 \mathrm{~b}$ & $1.02 \mathrm{ab}$ & $8.1 \mathrm{bc}$ & $129 \mathrm{e}$ & $0.29 \mathrm{a}$ \\
\hline IUB9 & $0.66 \mathrm{ef}$ & $0.62 \mathrm{c}$ & $1.03 \mathrm{a}-\mathrm{d}$ & $128 \mathrm{gh}$ & $0.97 \mathrm{~b}-\mathrm{e}$ & $7.6 \mathrm{fg}$ & $123 \mathrm{j}$ & $0.26 \mathrm{de}$ \\
\hline IUB10 & $0.68 \mathrm{~cd}$ & $0.63 \mathrm{bc}$ & $1.06 \mathrm{a}-\mathrm{c}$ & $134 \mathrm{c}$ & $1.01 \mathrm{a}-\mathrm{c}$ & $8.2 \mathrm{~b}$ & $133 \mathrm{~b}$ & $0.27 \mathrm{~b}-\mathrm{d}$ \\
\hline IUB11 & $0.68 \mathrm{~cd}$ & $0.66 \mathrm{a}-\mathrm{c}$ & $1.05 \mathrm{a}-\mathrm{d}$ & $139 \mathrm{ab}$ & 0.99 a-d & $8.1 \mathrm{~b}$ & $133 \mathrm{a}$ & $0.28 \mathrm{ab}$ \\
\hline IUB12 & $0.63 \mathrm{hi}$ & $0.63 \mathrm{bc}$ & $1.03 \mathrm{a}-\mathrm{d}$ & $132 \mathrm{~d}$ & $0.95 \mathrm{c}-\mathrm{e}$ & $7.5 \mathrm{gh}$ & $124 \mathrm{I}$ & $0.26 \mathrm{c}-\mathrm{e}$ \\
\hline IUB14 & $0.65 \mathrm{fg}$ & $0.63 \mathrm{bc}$ & $1.00 \mathrm{~b}-\mathrm{d}$ & $130 \mathrm{ef}$ & $0.93 \mathrm{de}$ & $7.5 \mathrm{gh}$ & $125 \mathrm{~h}$ & $0.25 \mathrm{de}$ \\
\hline IUB17 & $0.64 \mathrm{gh}$ & $0.62 \mathrm{c}$ & $0.99 \mathrm{~cd}$ & $127 \mathrm{hi}$ & $0.97 \mathrm{~b}-\mathrm{e}$ & $7.9 \mathrm{~cd}$ & $127 \mathrm{f}$ & $0.26 \mathrm{c}-\mathrm{e}$ \\
\hline IUB23 & $0.67 \mathrm{de}$ & $0.63 \mathrm{bc}$ & $1.03 \mathrm{a}-\mathrm{d}$ & $126 \mathrm{i}$ & $0.93 \mathrm{e}$ & 7.7 ef & $126 \mathrm{~g}$ & $0.26 \mathrm{de}$ \\
\hline $\begin{array}{c}\text { LSD } \\
(p \leq 0.05)\end{array}$ & 0.0157 & 0.0418 & 0.0668 & 1.7827 & 0.0615 & 0.1470 & 0.5829 & 0.0147 \\
\hline $\mathrm{CV}$ & 1.41 & 3.90 & 3.84 & 0.81 & 3.76 & 1.11 & 0.28 & 3.31 \\
\hline
\end{tabular}

Data are shown as mean of five replicates. Means followed by same letter(s) within the column are not significantly different according to least significance difference (LSD) test at $\mathrm{p} \leq 0.05$. SOD; superoxide dismutase activity, POD; peroxidase dismutase activity, CAT; catalase activity, APX; ascorbate peroxidase activity, POX; peroxidase activity 
of superoxide dismutase activity (14\%), peroxidase dismutase activity (15\%), and catalase activity (15\%). The strains IUB10 and IUB11 expressed the highest ascorbate peroxidase activity that was $14 \%$ more than the control. The maximum peroxidase activity was recorded by strain IUB6 was $15 \%$ more than control. The strains IUB2, IUB3, IUB10 and IUB11 showed an increase of $12,9,7$ and $11 \%$ in peroxidase activity, respectively.

\section{Wheat Trial}

\section{Growth Promoting Activity of Rhizobacterial Isolates in Wheat Seedling}

The selected strains were further evaluated for their growth promoting abilities in wheat crop. Seed inoculation with zinc solubilizing rhizobacteria significantly enhanced wheat growth under axenic conditions (Table 4). Statistical analysis showed that the strain IUB3 exhibited maximum shoot length, with $40 \%$ increase over the uninoculated control. The next strains that perform better were IUB11, IUB2, IUB6, and IUB10. These strains showed increase of 38, 35, 31, and $29 \%$ in shoot length, respectively. The maximum increase of $39 \%$ in root length was recorded by strain IUB11 followed by IUB3 and IUB2, which was 32 and $28 \%$ increased, respectively. The strain IUB17, IUB19 and IUB23 showed a similar effect on root length that increased up to $18 \%$ compared to the control. According to statistical analysis, the strain IUB11 showed the highest root/shoot ratio, followed by the strains IUB10 over the uninoculated control that increased by $32 \%$ and $31 \%$, respectively.

The results explored in (Table 4) showed that the inoculation of zinc-solubilizing rhizobacteria enhanced root colonization in wheat under axenic conditions. All applied strains showed a potential increase in root colonization as compared to the control. However, the strain IUB3 showed maximum root colonization $\left(81 \times 10^{4} \mathrm{cfu} \mathrm{g}^{-1}\right.$ root $)$ followed by strains IUB12, IUB10, and IUB5 that showed $62 \times 10^{4} \mathrm{cfu} \mathrm{g}^{-1}$ root, $57 \times 10^{4}$ cfu $\mathrm{g}^{-1}$ root and $55 \times 10^{4} \mathrm{cfu}^{-1}$ root, respectively. Among applied treatments, minimum root colonization $16 \times 10^{4} \mathrm{cfu} \mathrm{g}^{-1}$ root was observed by strain IUB17. However, all tested strains showed a significant increase in root colonization over control $\left(9 \times 10^{4} \mathrm{cfu} \mathrm{g}^{-1}\right.$ root $)$.

The results in Fig. 2 demonstrated the effectiveness of zinc-solubilizing rhizobacterai for increasing the leaf surface area, average root diameter, root surface area and root volume. The strain IUB11 showed maximum leaf area and average root diameter that was 31 and $33 \%$ more than control, respectively. The strain IUB2 showed the maximum increase of $28 \%$ in root surface area. While strain IUB4 showed a slight increase of $1 \%$ in root surface area that was non-significant as compared to control. The strain IUB6 showed the maximum increase of $37 \%$ in root volume followed

Table 4. Potential of zinc solubilizing rhizobacteria to improve growth parameters of wheat in jar trial.

\begin{tabular}{|c|c|c|c|c|c|}
\hline \multirow{2}{*}{ Treatments } & Shoot length & Root length & \multirow{2}{*}{$\frac{\text { Dry biomass }}{\mathrm{g} \mathrm{jar}^{-1}}$} & \multirow{2}{*}{$\frac{\mathrm{R} / \mathrm{S} \text { ratio }}{-}$} & \multirow{2}{*}{$\begin{array}{l}\text { Root colonization } \\
\mathrm{CFU} \times 10^{5} \mathrm{~mL}^{-1}\end{array}$} \\
\hline & \multicolumn{2}{|c|}{$\mathrm{cm}$} & & & \\
\hline Control & $17.0 \mathrm{k}$ & $4.4 \mathrm{~h}$ & $0.31 \mathrm{~d}$ & $0.22 \mathrm{e}$ & 91 \\
\hline IUB2 & $22.8 \mathrm{c}$ & $5.7 \mathrm{bc}$ & $0.42 \mathrm{a}$ & $0.27 b$ & $21 \mathrm{j}$ \\
\hline IUB3 & $23.8 \mathrm{a}$ & $5.8 \mathrm{c}$ & $0.41 \mathrm{a}$ & $0.28 \mathrm{ab}$ & $81 \mathrm{a}$ \\
\hline IUB4 & $21.2 \mathrm{fg}$ & $5.5 \mathrm{ce}$ & $0.37 \mathrm{bc}$ & $0.23 \mathrm{de}$ & $44 \mathrm{f}$ \\
\hline IUB5 & $21.2 \mathrm{f}$ & $5.3 \mathrm{fg}$ & $0.37 \mathrm{c}$ & $0.27 \mathrm{~b}$ & $55 \mathrm{~d}$ \\
\hline IUB6 & $22.2 \mathrm{~d}$ & $5.6 \mathrm{~cd}$ & $0.40 \mathrm{ab}$ & $0.28 \mathrm{ab}$ & $40 \mathrm{~g}$ \\
\hline IUB9 & $21.0 \mathrm{~g} \mathrm{~h}$ & $5.5 \mathrm{~d}-\mathrm{f}$ & $0.40 \mathrm{ab}$ & $0.24 \mathrm{~cd}$ & $40 \mathrm{~g}$ \\
\hline IUB10 & $21.8 \mathrm{e}$ & $5.6 \mathrm{~cd}$ & $0.36 \mathrm{c}$ & $0.29 \mathrm{a}$ & $57 \mathrm{c}$ \\
\hline IUB11 & $23.5 \mathrm{~b}$ & $6.2 \mathrm{a}$ & $0.40 \mathrm{ab}$ & $0.29 \mathrm{a}$ & $51 \mathrm{e}$ \\
\hline IUB12 & $20.7 \mathrm{i}$ & $5.4 \mathrm{e}-\mathrm{g}$ & $0.37 \mathrm{c}$ & $0.24 \mathrm{~cd}$ & $62 \mathrm{~b}$ \\
\hline IUB14 & $20.0 \mathrm{j}$ & $5.2 \mathrm{~g}$ & $0.37 \mathrm{c}$ & $0.24 \mathrm{~cd}$ & $32 \mathrm{I}$ \\
\hline IUB17 & $21.0 \mathrm{~g}$ & $5.3 \mathrm{~g}$ & $0.37 \mathrm{bc}$ & $0.25 \mathrm{c}$ & $16 \mathrm{k}$ \\
\hline IUB23 & $20.8 \mathrm{hi}$ & $5.2 \mathrm{~g}$ & $0.38 \mathrm{bc}$ & $0.27 \mathrm{ab}$ & $35 \mathrm{~h}$ \\
\hline $\operatorname{LSD}(p \leq 0.05)$ & 0.1842 & 0.1823 & 0.0274 & 0.0166 & 1.5438 \\
\hline $\mathrm{CV}$ & 0.52 & 2 & 4.32 & 3.80 & 2.20 \\
\hline
\end{tabular}

Data are shown as mean of five replicates. Means followed by same letter(s) within the column are not significantly different according to least significance difference (LSD) test at $\mathrm{p} \leq 0.05$. R/S ratio; root to shoot ratio 

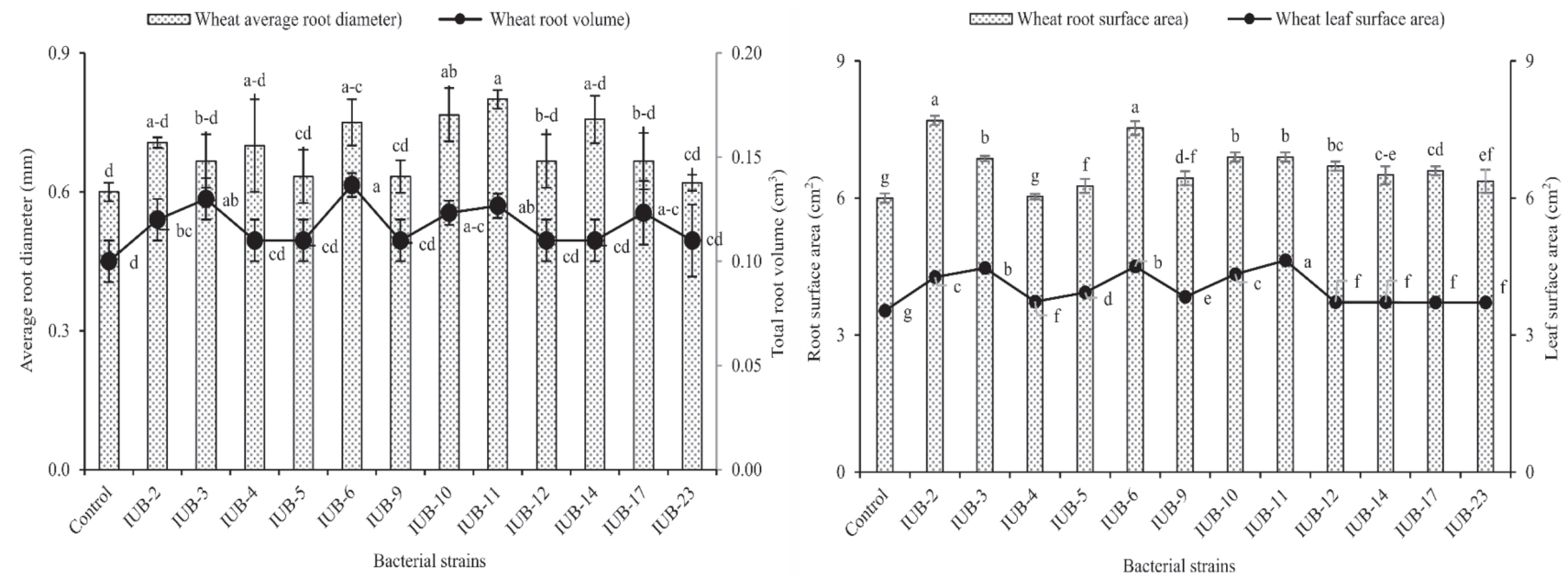

Fig. 2. Potential of zinc solubilizing rhizobacteria to improve root growth and leaf surface area in wheat seedling. Bars sharing same letter(s) does not differ significantly as par 5\% level of probability. Bars represent average root diameter a) and root surface area b) while Line represent total root volume a) and leaf surface area b).

by $30,27,23$ and $20 \%$ increase in root volume by strains IUB6, IUB11, IUB10 and IUB2, respectively.

\section{Effect of Zinc Solubilizing Bacterial Isolates on Physiology and Antioxidant Enzyme System of Wheat Seedlings}

Data in Table 5, showed the efficacy of zincsolubilizing bacteria in increasing chlorophyll a, chlorophyll b, and carotenoid content. The strain IUB6 and IUB2 showed similar results for chlorophyll-a contents. These strains showed maximum increase of $18 \%$ in chlorophyll-a content as compared to the control. The next strain that showed a significant increase in chlorophyll-a content was IUB10 which showed 14\% increase as compared to control. The strain IUB3, IUB9 and IUB23 showed a similar effect on chlorophyll-a content, where $12 \%$ increase was recorded. Results revealed that the strain IUB6 showed maximum increase of $17 \%$ in chlorophyll contents followed by strains IUB15 which showed $15 \%$ increase as compared to control. While the maximum increase of $16 \%$ in carotenoid content was recorded by strain IUB10. The strains IUB3, IUB2, and IUB6 were the following strains that perform better after IUB10. These strains showed similar results where $14 \%$ increase was recorded as compared to control.

All the applied treatments showed a significant effect on antioxidant enzymes such as superoxide dismutase activity (SOD), peroxidase dismutase activity (POD), catalase activity (CAT), ascorbate peroxidase activity (APX), and peroxidase activity (POX), in wheat seedlings under axenic conditions (Table 5). The data revealed that strain IUB2 showed the highest value for superoxide dismutase activity, with a $15 \%$ increase, followed by strains IUB3 and IUB6 that showed 13\% increase in SOD as compared to control. The strain IUB10 was the subsequent treatment that showed 11\% increase in SOD. The strain IUB3 showed the highest increase of $13 \%$ in peroxidase dismutase activity and ascorbate peroxidase activity. While the highest catalase activity was found in strain IUB10 followed by the strains IUB11, IUB3, and IUB2, which showed a $13 \%, 10 \%$, and $9 \%$ increase, respectively. The strain IUB11 showed the maximum increase of $15 \%$ in peroxidase activity. The subsequent strains that expressed better peroxidase activity were IUB10, IUB3, and IUB6 which showed 13, 12, and 9\% increase, respectively.

\section{Characterization of Zinc Solubilizing Bacteria}

The five best performing rhizobacterial strains that showed maximum results to improve seedling growth of maize and wheat under axenic conditions were selected for further in vitro evaluation for plant growth promoting attributes. The results of in vitro characterization are presented in table 6 . The selected strains were evaluated for exopolysaccharide production on agar plate assay. Appearance of mucoid growth around bacterial colony on RCV media indicated positive results for exopolysaccharides production. All the strains showed positive results for EPS production, siderophore production, hydrogen cyanide (HCN) production, protease activity, cellulose degradation ability and catalase activity. Catalase activity was considered positive if the strain form bubbles after pouring a drop of $\mathrm{H}_{2} \mathrm{O}_{2}$ bacterial colony. Among tested strains, only IUB2 and IUB10 showed solubilization of insoluble $\mathrm{P}$ in agar plate assay containing Pickovskay's nutrient media. All the tested strains were unable to produce ammonia $\left(\mathrm{NH}_{3}\right)$ in Christensen's urea broth and were reported as negative for $\mathrm{NH}_{3}$ production. Oxidase activity were also not detected in any tested strains. The tested strains showed positive results for indole-3-acetic acid (IAA) production in the presence 
Table 5. Potential of zinc solubilizing rhizobacteria to improve physiological parameters of wheat in jar trial.

\begin{tabular}{|c|c|c|c|c|c|c|c|c|c|}
\hline \multirow{2}{*}{ Treatments } & Chlorophyll a & Chlorophyll b & Carotenoid & SOD & POD & CAT & APX & POX \\
\cline { 2 - 11 } & \multicolumn{7}{|c|}{$\mu \mathrm{g} \mathrm{g}^{-1}$} \\
\hline Control & $0.52 \mathrm{e}$ & $0.58 \mathrm{~d}$ & $0.21 \mathrm{~d}$ & $128 \mathrm{~g}$ & $19.7 \mathrm{j}$ & $15.6 \mathrm{~g}$ & $177 \mathrm{i}$ & $0.30 \mathrm{e}$ \\
\hline IUB2 & $0.61 \mathrm{a}$ & $0.67 \mathrm{a}$ & $0.24 \mathrm{ab}$ & $147 \mathrm{a}$ & $22.1 \mathrm{~b}$ & $16.9 \mathrm{~cd}$ & $195 \mathrm{bc}$ & $0.32 \mathrm{~b}-\mathrm{d}$ \\
\hline IUB3 & $0.58 \mathrm{a}-\mathrm{d}$ & $0.67 \mathrm{ab}$ & $0.24 \mathrm{ab}$ & $144 \mathrm{~b}$ & $22.3 \mathrm{a}$ & $17.2 \mathrm{c}$ & $200 \mathrm{a}$ & $0.33 \mathrm{ab}$ \\
\hline IUB4 & $0.55 \mathrm{~b}-\mathrm{e}$ & $0.64 \mathrm{a}-\mathrm{c}$ & $0.22 \mathrm{~b}-\mathrm{d}$ & $136 \mathrm{e}$ & $20.1 \mathrm{~h}$ & $15.8 \mathrm{fg}$ & $183 \mathrm{~h}$ & $0.30 \mathrm{e}$ \\
\hline IUB5 & $0.54 \mathrm{c}-\mathrm{e}$ & $0.61 \mathrm{~cd}$ & $0.22 \mathrm{~b}-\mathrm{d}$ & $131 \mathrm{f}$ & $20.5 \mathrm{~g}$ & $16.4 \mathrm{e}$ & $191 \mathrm{de}$ & $0.30 \mathrm{de}$ \\
\hline IUB6 & $0.61 \mathrm{a}$ & $0.68 \mathrm{a}$ & $0.24 \mathrm{ab}$ & $143 \mathrm{bc}$ & $21.7 \mathrm{~d}$ & $16.8 \mathrm{~d}$ & $193 \mathrm{~cd}$ & $0.32 \mathrm{a}-\mathrm{c}$ \\
\hline IUB9 & $0.58 \mathrm{a}-\mathrm{c}$ & $0.67 \mathrm{ab}$ & $0.22 \mathrm{~b}-\mathrm{d}$ & $129 \mathrm{~g}$ & $20.0 \mathrm{hi}$ & $15.9 \mathrm{fg}$ & $189 \mathrm{ef}$ & $0.31 \mathrm{c}-\mathrm{e}$ \\
\hline IUB10 & $0.59 \mathrm{ab}$ & $0.67 \mathrm{a}$ & $0.25 \mathrm{a}$ & $141 \mathrm{c}$ & $21.6 \mathrm{~d}$ & $18.0 \mathrm{a}$ & $199 \mathrm{a}$ & $0.34 \mathrm{ab}$ \\
\hline IUB11 & $0.53 \mathrm{de}$ & $0.65 \mathrm{a}-\mathrm{c}$ & $0.24 \mathrm{a}-\mathrm{c}$ & $139 \mathrm{~d}$ & $21.9 \mathrm{c}$ & $17.7 \mathrm{~b}$ & $197 \mathrm{ab}$ & $0.34 \mathrm{a}$ \\
\hline IUB12 & $0.52 \mathrm{e}$ & $0.63 \mathrm{a}-\mathrm{c}$ & $0.23 \mathrm{a}-\mathrm{d}$ & $135 \mathrm{e}$ & $20.5 \mathrm{~g}$ & $15.9 \mathrm{f}$ & $186 \mathrm{gh}$ & $0.31 \mathrm{c}-\mathrm{e}$ \\
\hline IUB14 & $0.53 \mathrm{de}$ & $0.64 \mathrm{a}-\mathrm{c}$ & $0.23 \mathrm{a}-\mathrm{d}$ & $131 \mathrm{f}$ & $19.9 \mathrm{ij}$ & $16.1 \mathrm{f}$ & $187 \mathrm{fg}$ & $0.32 \mathrm{~b}-\mathrm{d}$ \\
\hline IUB17 & $0.53 \mathrm{e}$ & $0.62 \mathrm{~b}-\mathrm{d}$ & $0.22 \mathrm{~cd}$ & $129 \mathrm{~g}$ & $20.7 \mathrm{f}$ & $16.4 \mathrm{e}$ & $186 \mathrm{fg}$ & $0.31 \mathrm{c}-\mathrm{e}$ \\
\hline IUB23 & $0.58 \mathrm{a}-\mathrm{c}$ & $0.64 \mathrm{a}-\mathrm{c}$ & $0.23 \mathrm{a}-\mathrm{d}$ & $132 \mathrm{f}$ & $21.1 \mathrm{e}$ & $16.8 \mathrm{~d}$ & $184 \mathrm{gh}$ & $0.31 \mathrm{c}-\mathrm{e}$ \\
\hline$L S D(p \leq 0.05)$ & 0.0466 & 0.0474 & 0.0227 & 1.6783 & 0.1567 & 0.2857 & 3.3900 & 0.0191 \\
\hline CV & 4.97 & 4.38 & 5.91 & 0.74 & 0.45 & 1.03 & 1.06 & 3.59 \\
\hline
\end{tabular}

Data are shown as mean of five replicates. Means followed by same letter(s) within the column are not significantly different according to least significance difference (LSD) test at $\mathrm{p} \leq 0.05$. SOD; superoxide dismutase activity, POD; peroxidase dismutase activity, CAT; catalase activity, APX; ascorbate peroxidase activity, POX; peroxidase activity

and absence of L-tryptophane with a variable degree of IAA production. The strain IUB11 recorded the Maximum IAA production $\left(2.7 \mu \mathrm{g} \mathrm{mL}^{-1}\right)$ in the absence of L-tryptophan. Strains IUB3 and IUB6 showed similar results for IAA production in the absence of L-tryptophane, where the recorded production of IAA was $2.4 \mu \mathrm{g} \mathrm{mL}^{-1}$. In the presence of L-tryptophan, the maximum IAA production was showed by the strain IUB10 followed by the strains IUB11 and IUB3 with $15.2 \mu \mathrm{g} \mathrm{mL}^{-1}, 13.9 \mu \mathrm{g} \mathrm{mL}^{-1}$ and $13.6 \mu \mathrm{g} \mathrm{mL}^{-1}$ of indole acetic acid production, respectively.

\section{Identification of Bacterial Strains}

The five promising zinc solubilizing rhizobacterial isolates having manifold growth endorsing characters in maize and wheat were identified through $16 \mathrm{~S}$ rRNA partial sequencing technique. On the bases of resemblance with different bacillus species, these strains were identified as Bacillus velezensis (IUB3), Bacillus subtilis (IUB2 and IUB6), Bacillus vallismortis (IUB10) and Bacillus megaterium (IUB11) as shown in Fig. 3. The resulting sequences were also deposited in NCBI Genbank data base with the accession numbers MN696213, MN696212, MN696214, MN696215 and MN696216, respectively.

\section{Discussion}

The experiment was carried out for evaluating the plant growth promoting potential of zinc solubilizing rhizobacteria isolated from wheat and maize rhizosphere. The results expressed that inoculation of zinc solubilizing rhizobacteria significantly improved the growth of maize and wheat crops (Fig. 4). In our study strains were tested for the zinc solubilization ( $\mathrm{ZnO})$ qualitatively and quantitatively. Best strains for the qualitative and quantitative zinc solubilization were IUB2, IUB3 and IUB9 that is thought to be based on organic acid production. The solubilization of unavailable $\mathrm{ZnO}$ in the broth medium could be due to the release of organic acid by the zinc solubilizing rhizobacteria that decreases the $\mathrm{pH}$ of broth medium and solubilize the unavailable $\mathrm{ZnO}$. This work is with the line of Hussain et al. [17], who reported that out of 52 bacterial isolates, only 14 bacterial strains showed a strong ability of zinc solubilization. Similar results were also reported by Sharma et al. [32], who reported that PGPR solubilized $\mathrm{Zn}$ through production of organic acids.

The results of the jar trial showed that inoculation of zinc solubilizing bacteria improved the shoot length, root length, root/shoot ratio and total dry biomass as compared to the uninoculated control in both wheat 


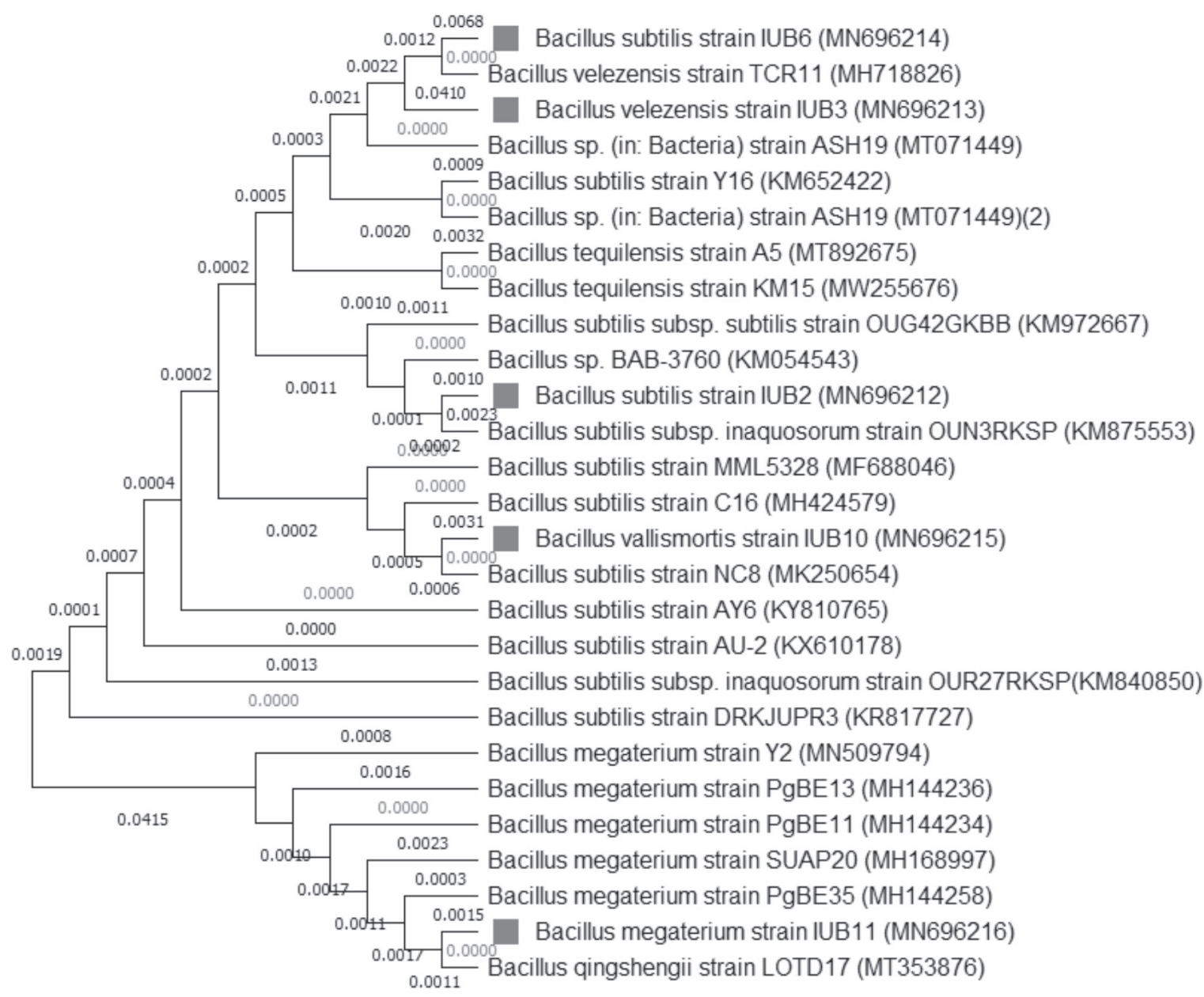

Fig. 3. Neighbor joining tree of Bacillus subtilis (IUB2 and IUB6), Bacillus velezensis (IUB3), Bacillus vallismortis (IUB10) and Bacillus megaterium (IB11) constructed by closely related strains.
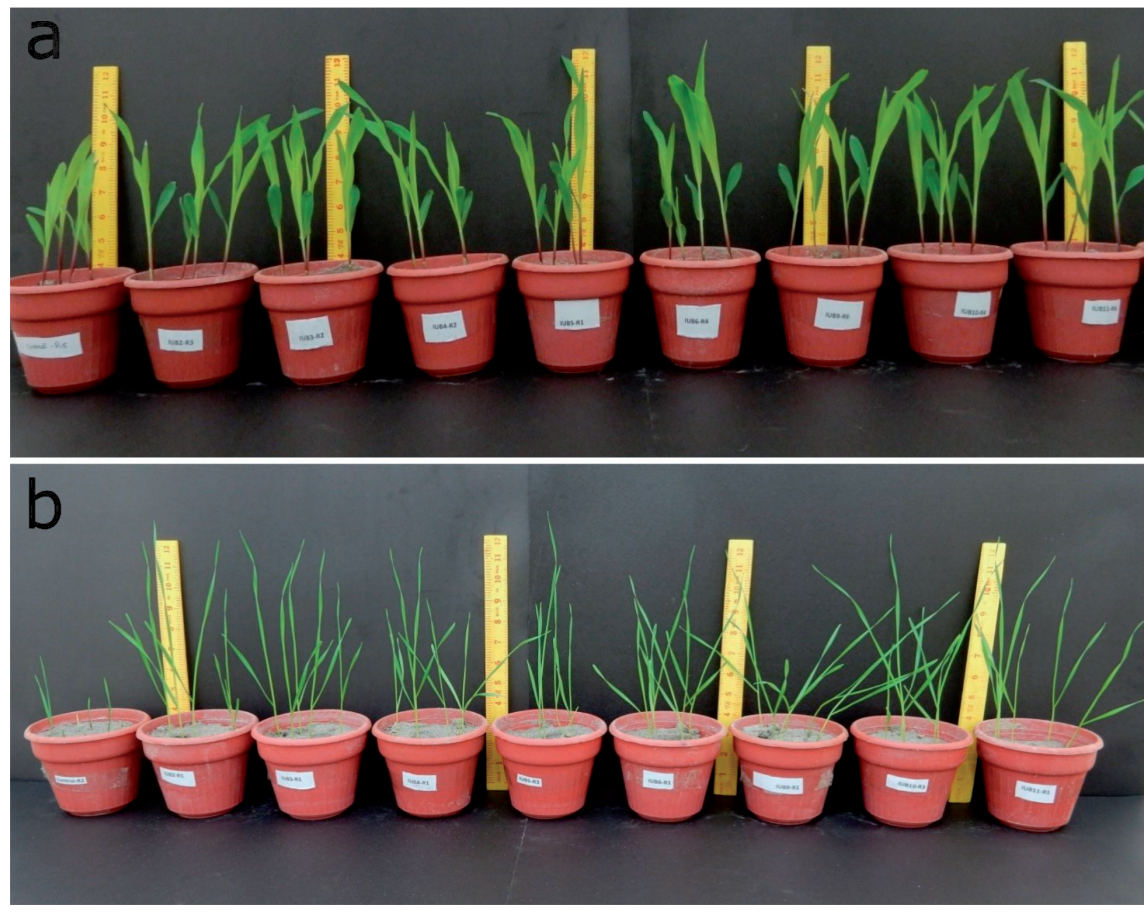

Fig. 4. Effect of zinc solubilizing rhizobacteria and enriched compost on growth of maize a) and wheat b) seedlings. The jars are arranged from left to right as; Control, IUB2, IUB3, IUB4, IUB5, IUB6, IUB9, IUB10 and IUB11. 
and maize crops. The strain IUB3 showed maximum shoot length in both wheat and maize crop. However maximum root length was shown by the strain IUB11. The highest total dry weight was shown by the strains IUB11 and IUB10 in maize crop and zinc solubilizing bacterial strains (IUB9, IUB6 and IUB2) also increased these growth parameters in wheat crop. The increased shoot length, root length, and total dry biomass might be due to the solubilization of zinc, synthesis of various plant growth regulators, phosphorus solubilization and indole acetic acid production by the zinc solubilizing rhizobacteria. The improvement in growth parameters might be due increased availability of nutrients and production of plant growth regulators by plant growth promoting bacteria [33]. The results are similar as described by Goteti et al. [34] and Vaid et al. [35], where they described that inoculation of zinc solubilizing bacteria significantly improved the shoot length, root length and total dry biomass of rice, soybean as well as maize crops. These results are also supported by Hussain et al. [17], who described that use of zinc solubilizing bacteria enhanced shoots fresh biomass, fresh root biomass, shoot length, root length, shoot dry biomass, root dry biomass as well as total dry biomass of crop.

It was found that inoculation of zinc solubilizing rhizobacteria significantly increased the leaf surface area of both maize and wheat crop. This increase in the leaf area might be due to the enhanced chlorophyll content caused by increasing the solubilization of essential nutrients in the crop leaves by zinc solubilizing rhizobacteria, which increased the leaf area of crops. These results are in accordance with Nadeem et al. [36] and Ahmad et al. [37], who described that the application of zinc solubilizing rhizobacteria enhanced the chlorophyll content in the mungbean and maize crops.

Root growth such as average root diameter, root surface area, and root volume were also improved by using zinc solubilizing rhizobacteria in the maize and wheat crop. This improvement in the root growth parameter might be due to increase in the zinc concentration in the plant roots by zinc solubilizing rhizobacteria. These results are similar to Fan et al. [38], who stated that root surface area and root hair are enhanced through the inoculation of zinc solubilizing bacteria. These results are also supported by Vaid et al. [35], who concluded that root growth in the rice plants enhanced by the application of zinc solubilizing bacteria.

Chlorophyll a, chlorophyll b, and carotenoid content also improved by applying zinc solubilizing rhizobacteria both in the maize and wheat crops. It could be due to the increase in the leaf area that significantly improved the chlorophyll content. These results are according to the results of Kang et al. [39]. Similar results are also reported by Hussain et al. [17] who stated that inoculation of zinc solubilizing bacterial isolates enhanced the chlorophyll content of maize crop.

The inoculation of plant growth promoting rhizobacteria also increased the superoxide dismutase activity (SOD), peroxidase activity (POX), peroxidase dismutase activity (POD), catalase activity (CAT) and ascorbate peroxidase activity (APX) in the leaves of both maize and wheat crops. The increase in the amount of antioxidants enzymes SOD, POX, POD, CAT and APX might be due to an increase in the amount of nutrients, especially zinc, for the crops by the zinc solubilizing rhizobacteria that improved amount

Table $6 . \mathrm{NH}_{3}$ production, Siderophore production, $\mathrm{HCN}$ production, EPS production phosphate solubilization and enzymatic activity of zinc solubilizing rhizobacteria.

\begin{tabular}{|c|c|c|c|c|c|c|}
\hline \multicolumn{2}{|c|}{ Biochemical characters } & IUB2 & IUB3 & IUB6 & IUB10 & IUB11 \\
\hline \multirow{2}{*}{$\begin{array}{c}\text { IAA } \\
\text { production }\end{array}$} & With L-trp & 13.4 & 13.6 & 14.1 & 15.2 & 13.9 \\
\hline & Without L-trp & 2.2 & 2.4 & 2.4 & 2.2 & 2.7 \\
\hline \multicolumn{2}{|c|}{$\mathrm{NH}_{3}$ production } & - & - & - & - & - \\
\hline \multicolumn{2}{|c|}{ Siderophore production } & + & + & + & + & + \\
\hline \multicolumn{2}{|c|}{$\mathrm{HCN}$ production } & + & + & + & + & + \\
\hline \multicolumn{2}{|c|}{ EPS production } & + & + & + & + & + \\
\hline \multicolumn{2}{|c|}{ Phosphate solubilization } & + & - & - & + & - \\
\hline \multicolumn{2}{|c|}{ protease activity } & + & + & + & + & + \\
\hline \multicolumn{2}{|c|}{ Cellulose degradation activity } & + & + & + & + & ++ \\
\hline \multicolumn{2}{|c|}{ Catalase activity } & + & + & + & + & + \\
\hline \multicolumn{2}{|c|}{ Oxidase activity } & - & - & - & - & - \\
\hline
\end{tabular}

Here: $\mathrm{NH}_{3}=$ Ammonia, $H C N=$ Hydrogen cyanide, EPS = Exopolysaccharide; Positive sign (+) indicates the presence of trait; double positive sign $(++)$ indicate strong presence of trait; negative sign (-) indicates the absence of trait. 
of antioxidants enzymes in the crop leaves. These results are in line with those of Chakraborty et al. [40], who reported that inoculation of bacillus species B. safensis enhanced the amount of antioxidant enzymes in the crop leaves.

For the testing of plant growth promoting abilities, only five best strains were selected. It was found that all the strains were positive for siderophore and $\mathrm{HCN}$ production. These results are in line with the work of Scagliola et al. [41], who stated that Rhizobium species and Agrobacterium tumefaciens strains synthesizes the siderophore. Shoukry et al. [42] described that zinc solubilizing bacterial strains can synthesize the siderophore and HCN that provides the resistance to the crops against the pathogens and increased the supply of iron to the crop plant. All the selected zinc solubilizing strains also showed positive results for exopolysaccharides production. According to Tewari and Arora [43], these results are reported that selected zinc solubilizing bacterial strains produce exopolysaccharides. All the tested strains gave positive results for IAA production both in the absence and presence of L-tryptophan. These results are in according to the results reported by Ramesh et al. [44]. Exopolysaccharides enhanced the ability of bacterial strains to colonize the roots. Strains IUB2 and IUB10 gave positive results for phosphate solubilization by forming clear zone in the plate assay. These results are in line with the work of Matse et al. [45] who described that Pseudomonas fluorescent strain showed the results for phosphate solubilization. The biochemical characteristics such as EPS, HCN, siderophore production promote plant growth through providing essential nutrients and suppressing pathogens $[42,46]$. Plant growth regulators and IAA production mitigate the salt and drought stress and promote plant growth [47].

All the tested strains showed positive results for protease and catalase activity and cellulose degradation ability in agar plate assay in the current study. Similar results were found by Iqbal et al. [25], who reported positive results for catalase and protease activity of different rhizobacterial and endophytic strains. He also reported the cellulose degradation ability of Bacillus strains. These enzymes were comprehensively reported for their effectiveness in tolerating stress [48].

The data showed that all the zinc solubilizing bacteria have root colonization ability; however, the highest root colonization ability was given by the strain IUB2 in the maize crop and the strain IUB3 in the wheat crop. Rezaee-Niko et al. [49] supported these results and presented that seed inoculation enhanced root colonization, which ultimately resulted in improved growth. Root colonization enhanced uptake of nutrients and promote plant growth [26].

All the tested strains showed a negative value for ammonia production. Similar results have also been reported by Mumtaz et al. [24] in which four strains showed negative results for ammonia production.
All the zinc solubilizing bacterial strains also gave negative results for the oxidase activity. These results have also been supported by Dinesh et al. [50]. Similar results have also been described by Mumtaz et al. [24] who stated that from selected 6 bacterial strains 3 strains showed negative value for oxidase activity. These enzymes protect the crops from harmful pathogens and improve plant growth and development [42].

\section{Conclusions}

Zinc solubilizing bacterial strains and enriched compost improved the growth of maize and wheat crops. However, strains IUB2, IUB3, IUB6, IUB10 and IUB11 perform better to promote seedling growth. The tested strains possess several biochemical and enzymatic activities in laboratory studies. These strains also increased the availability of zinc through solubilization. Hence, combined application of zinc solubilizing rhizobacterial strains and enriched compost perform better than sole inoculation. Therefore, bioactive $\mathrm{Zn}$-enriched compost may be formulated by using a consortium of these strains after field evaluation.

\section{Acknowledgments}

The authors acknowledged Soil Microbiology and Biotechnology Laboratory, Department of Soil Science, Faculty of Agriculture and Environment, The Islamia University of Bahawalpur, to provide space and facilities to conduct research effectively. The financial funding was done by Higher Education Commission (HEC) of Pakistan under National Research Program for Universities (NRPU) project number "6292/Punjab/ NRPU/R\&D/HEC/2016.

\section{Conflict of Interest}

The authors declared that they have no conflict of interest.

\section{References}

1. SUGANYA A., SARAYANAN A. Effect of Graded levels of $\mathrm{Zn}$ in combination with or without microbial inoculation on $\mathrm{Zn}$ transformation in soil, yield and nutrient uptake by maize for red soil. Green Farming, 7, 938, 2016.

2. XI-WEN Y., XIAO-HONG L., XIN-CHUN G., WILLIAM, YU-XIAN C. Foliar zinc fertilization improves the zinc nutritional value of wheat (Triticumaestivum L.) grain. Afri J. Biotechnol 10, 14778, 2013.

3. EFE L., YARPUZ E. The effect of zinc application methods on seed cotton yield, lint and seed quality of cotton (Gossypium hirsutum L.) in east Mediterranean region of Turkey. Afri J. Biotechnol, 10, 8782, 2013. 
4. World Health Organization (WHO). The World Health Report, Geneva, Switzerland, 2010.

5. DESHMUKH D.P., NAVALE A.M., DEOKAR C.D., Influence of Zinc Solubilising Consortiums on Yield Parameters of Suru Sugarcane, 2019.

6. HUSSAIN A., AHMAD M., NAFEES M., IQBAL Z., LUQMAN M., JAMIL M., MAQSHOOF A., MORAPOBLETE F., AHMAR S., CHEN J.T., ALYEMENI M.N. Plant-growth-promoting Bacillus and Paenibacillus species improve the nutritional status of Triticum aestivum L. Plos one, 15 (12), e0241130, 2020.

7. KHALID N., K M., AQEEL M. Amelioration of adverse effects of simulated acid rain (SAR) on growth and yield attributes of sunflower (Helianthus annuus L.) by growth tonics. Pak J Bot, 45, 1989, 2013.

8. HAFEEZ B., KANIF Y.M., SALEEM M. Role of Zinc in plant nutrition- A Review. Am. J. Exp. Agric., 3 (2), 374, 2013.

9. BALASUBRAMANIAN V., BURESH R.J., BELL. M. Zinc International Rice Research Institute. ESPR, 0944, 2015.

10. KHANGHAHI M.Y., PIRDASHT H. RAHIMIAN G. NEMATZADEH, GHAJAR M. Potassium solubilising bacteria (KSB) isolated from rice paddy soil: from isolation, identification to $\mathrm{K}$ use efficiency. Symbiosis. ESPR, 0944, 2017.

11. RENGEL Z. Availability of $\mathrm{Mn}, \mathrm{Zn}$ and $\mathrm{Fe}$ in the rhizosphere. Soil Sci. Plant Nutr, 15 (2), 397, 2015.

12. MISHRA D.J., SINGH R., MISHRA U.K., SHAHI S.K. Role of bio-fertilizer in organic agriculture: a review. Res. J. Recent Sci, 2, 39, 2013

13. SARATHAMBAL C., ILAMURUGU K., BALACHANDAR C., CHINNADURAI, YOGITA G. Characterization and crop production efficiency of diazotrophic isolates from the rhizosphere of semi-arid tropical grasses of India. Appl. Soil Ecol, 87, 1, 2015.

14. MISHRA D.J., SINGH R., MISHRA U.K., SHAHI S.K. Role of bio-fertilizer in organic agriculture: a review. Res. J. Rec. Sci. 2, 39, 2013.

15. SARATHAMBAL C., ILAMURUGU K., BALACHANDAR D., CHINNADURAI C., YOGITA G. Characterization and crop production efficiency of diazotrophic isolates from the rhizosphere of semi-arid tropical grasses of India. Appl. Soil Ecol. 87, 1, 2015.

16. WANG X., FAN J., XING Y., XU G., WANG H., DENG J., WANG Y., ZHANG F., LI P., LI Z. The effects of mulch and nitrogen fertilizer on the soil environment of crop plants. Adv. Agron. 153, 121, 2019.

17. HUSSAIN A., ARSHAD M., ZAHIR Z.A., ASGHAR M. Prospects of zinc solubilizing bacteria for enhancing growth of maize. Pak. J. Agric. Sci., 52 (4), 915, 2015.

18. HUSSAIN A., AHMAD M., NAFEES M., IQBAL Z., LUQMAN M., JAMIL M., MAQSOOD A., MORAPOBLETE F., AHMAR S., CHEN J.T., ALYEMENI M.N. Plant-growth-promoting Bacillus and Paenibacillus species improve the nutritional status of Triticum aestivum L. Plos one, 15 (12), p.e0241130, 2020.

19. AHEMAD M., KIBERT M. Mechanisms and applications of plant growth promoting rhizobacteria: current perspective. Journal of King Saud University-Science, 26, $1,2014$.

20. VERMA M., MISHRA J., ARORA N.K. Plant growthpromoting rhizobacteria: diversity and applications. In: SOBTI R., ARORA N.K., KOTHARI R. (eds) Environmental biotechnology: for sustainable future. Springer, Singapore, 129, 2019.
21. GOTETI P.K., DANIEL L., EMMANUEL A., DESAI S., HASSAN M., SHAIKH A. Prospective zinc solubilising bacteria for enhanced nutrient uptake and growth promotion in maize (Zea mays L.). Int. J. Microbiol., 1-7, 2013A.

22. EGAMBERDIEYA D., WIRTH S., BELLINGRATHKIMURA S.D., MISHRA J., ARORA N.K. Salt-tolerant plant growth promoting rhizobacteria for enhancing crop productivity of saline soils. Front Microbiol, 10, 2791, 2019.

23. FASIM F., AHMED N., PARSONS R., GADD G.M Solubilization of zinc salts by a bacterium isolated from the air environment of a tannery. FEMS Microbiology Letters 213, 1, 2002.

24. MUMTAZ M.Z., AHMAD M., JAMIL M., HUSSAIN T. Zinc solubilizing Bacillus spp. potential candidates for biofortification in maize. Microbiol Resea, 202, 51, 2017.

25. HOAGLAND D.R., ARNON D.I. The water-culture method for growing plants without soil. California Agricultural Experiment Station Circular, 347, 1, 1950.

26. IQBAL Z., AHMAD M., JAMIL M., AKHTAR M.F.U.Z. Appraising the potential of integrated use of Bacillus strains for improving wheat growth. Int J Agric Biol , 24 (6), 1439, 2020.

27. PIKOVSKAYA R.I. Mobilization of phosphorous in soil in connection with vital activity of some microbial species. Mikrobiologiya, 17, 363, 1948.

28. SCHWYN B., NEILANDS J. Universal chemical assay for the detection and determination of siderophores. The Annual Review of Biochemistry, 160, 47, 1987.

29. PATTEN C.L., GLICK B.R. Role of Pseudomonas putida indole acetic acid in development of the host plant root system. Applied and Environmental Microbiology 68, 3795, 2002.

30. CHENEBY D., PERREZ S., DEVROE C., HALlET S., COUTON Y., BIZOUARD F., IURETIG G., GERMON J.C., PHILIPPOT L. Denitrifying bacteria in bulk and maize rhizospheric soil: diversity and $\mathrm{N}_{2} \mathrm{O}$-reducing abilities. Can. J. Microbiol., 50, 469, 2004.

31. STEEL K.J. The oxidase reaction as a toxic tool. Journal of General Microbiology 25, 297, 1961.

32. SHARMA S.K., RAMESH A., SHARMA M.P., JOSHI O.P., GOYAERTS B., STEENWERTH K.L., KARLEN D.L. Microbial community structure and diversity as indicators for evaluating soil quality. In: E. Lichtfouse (ed.), Biodiversity, Biofuel, Agroforestry and Conservation Agriculture, Sustainable Agriculture Review 5. Springer Science + Business Media B.V. The Netherlands, 1, 317, 2014.

33. AHMAD M., WANG X., HILGER T.H., LUQMAN M., NAZLI F., HUSSAIN A., ZAHIR Z.A., LATIF M., SAEED Q., MALIK H.A. MUSTAFA A. Evaluating Biochar-Microbe Synergies for Improved Growth, Yield of Maize, and Post-Harvest Soil Characteristics in a SemiArid Climate. Agronomy. 10 (7), 1055, 2020.

34. GOTETI P.K., EMMANUEL L.D.A., DESAI A., SHAIK M.H.A. Prospective zinc solubilising bacteria for enhanced nutrient uptake and growth promotion in maize (Zea mays L.). Int. J. Microbiol, 3, 185, 2013 B.

35. VAID S., KUMAR A., SHARMA A., SHUKLA A., SRIVASTAVA P. Effect of Zn solubilizing bacteria on growth promotion and $\mathrm{Zn}$ nutrition of rice. Soil Sci. Plant Nutr, 14, 889, 2019.

36. NADEEM S.M., ZAHIR Z.A., NAVEED M., ARSHAD M. Preliminary investigations on inducing salt tolerance in maize through inoculation with rhizobacteria 
containing ACC deaminase activity. Can. J. Microbiol, 53, 1141, 2007.

37. AHMAD M., ZAHIR Z.A., KHALID M., NAZLI F., ARSHAD M. Efficacy of Rhizobium and Pseudomonas strains to improve physiology, ionic balance and quality of mung bean under salt-affected conditions on farmer's fields. Plant Physiol Biochem, 63, 170, 2013.

38. FAN M., LIU Z., NAN L., WANG E., CHEN W., LIN Y., WEI G. Isolation, characterization, and selection of heavy metal-resistant and plant growth-promoting endophytic bacteria from root nodules of Robinia pseudoacacia in a $\mathrm{Pb} / \mathrm{Zn}$ mining area. Microbiol Res, 217, 51, 2018.

39. KANG S.M., RADHAKRISHNAN A., YOU Y.H., JOO G.J., LRR I.L., LRR K.E., KIM J.H. Phosphate solubilizing Bacillus megaterium mj1212 regulates endogenous plant carbohydrates and amino acids contents to promote mustard plant growth. Ind Microbiol, 54 (4), 427, 2014.

40. CHARABORTY U., CHAKRABORTY B.N., CHAKRABORTY A.P. CHAKRABORTY, DEY P.L. Water stress amelioration and plant growth promotion in wheat plants by osmotic stress tolerant bacteria. World $\mathrm{J}$ Microbiol Biotechnol, 29, 789, 2013.

41. SCAGLIOLA M., PII Y., MIMMO T., CESCO S., RICCIUTI P., CRECCHIO C. Characterization of plant growth promoting traits of bacterial isolates from the rhizosphere of barley (Hordeum vulgare L.) and tomato (Solanum lycopersicon L.) grown under Fe sufficiency and deficiency. Plant Physiol Biochem, 107, 187, 2016.

42. SHOUKRY A., HASSAN E., EL-GHOMARY A. Assessment of indole acetic acid production from Rhizobium leguminosarum strains. Curr. Sci. Int, 7 (1), 60, 2018.

43. TEWARI S., ARORA N.K. Role of salicylic acid from Pseudomonas aeruginosa PF23EPS+ in growth promotion of sunflower in saline soils infested with phytopathogen Macrophomina phaseolina. Environ sustain, 1, 49, 2018.
44. RAMESHA A., SHARMA S.K., SHARMA M.P., YADAV N., JOSHI O.P. Inoculation of zinc solubilizing Bacillus aryabhattai strains for improved growth, mobilization and biofortification of zinc in soybean and wheat cultivated in vertisols of central India. Appl. Soil Ecol, 73, 87, 2014.

45. MATSE D.T., HUANG C., HUANG Y., YEN M. Effects of coinoculation of Rhizobium with plant growth promoting rhizobacteria on the nitrogen fixation and nutrient uptake of Trifolium repens in low phosphorus soil. J. Plant Nutr., 43 (5), 739, 2020.

46. JAZCZAREK M., RACHWAL K., MARZEC A., GRZADZIEL J., PALUSINSKA-SZYSZ M. Signal molecules and cell-surface components involved in early stages of the legume-rhizobium interactions. Appl. Soil Ecol, 85, 94, 2015.

47. ATAJAN F.A., ZOHAN M.H.S. Alleviation of salt stress in lettuce (Lactuca sativa L.) by plant growth-promoting rhizobacteria. JHPR, 3, 67, 2020.

48. VAISHNAY A., SINGH J., SINGH P., RAJPUT R.S., SINGH H.B., SHARMA B.K. Sphingobacterium sp. BHU-AV3 induces salt tolerance in tomato by enhancing antioxidant activities and energy metabolism. Front Microbiol, 2020.

49. REZAEE-NIKO B., ENAYATIZAMIR N., NOROUZI MASIR M. Effect of zinc solubilizing growth promoter bacterium on plant growth under laboratory conditions. Agri eng, 41 (2), 113, 2018.

50. DINESH R., SRINIVASAN V., HAMZA S., SARATHAMBAL C., ANKE GOWDA S.J., GANESHAMURTHY A.N., GUPTA S.B., APARNA V., NAIR K.P., SUBILA A., LIKINA A., DIVYA V.C. Isolation and characterization of potential $\mathrm{Zn}$ solubilizing bacteria from soil and its effects on soil $\mathrm{Zn}$ release rates, soil available $\mathrm{Zn}$ and plant $\mathrm{Zn}$ content. Geoderma, 321, 173, 2018. 